\title{
The release of wastewater contaminants in the Arctic: A case study from Cambridge Bay, Nunavut, Canada ${ }^{\text {is }}$
}

\author{
Luis G. Chaves-Barquero a, b, Kim Hoang Luong ${ }^{\text {c }}$, C.J. Mundy ${ }^{\text {a }}$, Charles W. Knapp ${ }^{\text {d, }}$ \\ Mark L. Hanson ${ }^{a}$, Charles S. Wong a, b, c, * \\ a Department of Environment and Geography, University of Manitoba, Winnipeg, MB, R3T 2N2, Canada \\ ${ }^{\mathrm{b}}$ Escuela de Química, Instituto Tecnológico de Costa Rica, Cartago, 159-7050, Costa Rica \\ ${ }^{\mathrm{c}}$ Richardson College for the Environment, Department of Environmental Studies and Sciences and Department of Chemistry, The University of Winnipeg, \\ Winnipeg, MB, R3B 2E9, Canada \\ ${ }^{\mathrm{d}}$ Department of Civil and Environmental Engineering, University of Strathclyde, Glasgow, Scotland, G1 1XJ, United Kingdom
}

\section{A R T I C L E I N F O}

\section{Article history:}

Received 15 May 2016

Received in revised form

15 July 2016

Accepted 16 July 2016

Available online 26 July 2016

\section{Keywords:}

Arctic

Pharmaceuticals

Wastewater lagoons

Risk assessment

Nutrients

\begin{abstract}
A B S T R A C T
The treatment of municipal wastewater in the Arctic is challenging due to a variety of financial, operational, climatic and technical issues. To better understand the efficacy of current wastewater treatment in this region and the hazard posed to receiving waters, we assessed the occurrence of nutrients and contaminants (i.e., pharmaceuticals, antibiotic resistance genes) as they moved through a lagoon-based treatment system in Cambridge Bay, Nunavut, Canada. Wastewater treatment in this community is performed by the use of a lagoon-tundra wetland system that is discharged into the marine environment and is representative of current common practices throughout the region. In 2014, samples were collected before and during lagoon discharge from two locations in the main lagoon, one location downstream from the lagoon effluent and three locations offshore. Grab samples were collected to measure nutrients (e.g., total nitrogen and phosphorus) and the presence of antibiotic resistance genebearing microbes, and Polar Organic Chemical Integrative Samplers (POCIS) were deployed to collect passively organic contaminants in all locations. A total of six pharmaceuticals were detected from a screen of twenty-eight analytes during the study: atenolol, carbamazepine, clarithromycin, metoprolol, sulfamethoxazole and trimethoprim. The greatest concentrations of nutrients, antibiotic resistance genes (ARGs), and pharmaceuticals were found in sampling locations within the treatment lagoon. Offshore of the release point, we observed limited to no detection of pharmaceuticals and ARGs, but no change in total nitrogen and phosphorus from pre-release. We conclude that the current concentrations of monitored pharmaceuticals do not pose a significant hazard at this time to aquatic organisms in Cambridge Bay.
\end{abstract}

(๑) 2016 Elsevier Ltd. All rights reserved.

\section{Introduction}

Organic contaminants in wastewater effluents, including pharmaceuticals, are released to aquatic ecosystems and have been found to pose a hazard under certain conditions to receiving waters; this poses a challenge for current wastewater treatment practices in many regions (Fent et al., 2006). Many pharmaceuticals

\footnotetext{
This paper has been recommended for acceptance by Dr. Chen Da.

* Corresponding author. Richardson College for the Environment, Department of Environmental Studies and Sciences and Department of Chemistry, The University of Winnipeg, Winnipeg, MB, R3B 2E9, Canada.

E-mail address: wong.charles.shiu@alum.mit.edu (C.S. Wong).
}

such as anti-inflammatory drugs, antidepressants and antibiotics are not fully eliminated in the body, and thus enter the sewage system as both parent compounds and their metabolites (Vasskog et al., 2009). Many current wastewater treatment systems are not specifically designed to eliminate organic contaminants and, as a consequence, many of these pollutants are able to persist through wastewater treatment processes (Gunnarsdottir et al., 2013). In addition, monitoring actions for most micropollutants have not been well established in most wastewater treatment facilities (Bolong et al., 2009). Another concern is the presence of organisms that carry antibiotic resistance genes (ARGs), which can threaten public health (Rowan, 2011). Antibiotic resistance genes in the environment are often present due to human and veterinary use of 
antibacterial and antimicrobial products (Smith et al., 2004; Graham et al., 2011). Nutrient enrichment has also been a potential hazard to the aquatic environment with increasing eutrophication in freshwater and enclosed marine systems downstream of areas of urbanization (Smith, 2003). While the releases of effluents have been characterized for many countries and regions of the world (Luo et al., 2014), little to no work has been performed to quantify organic micropollutants and their risk in polar regions because of the difficulties associated with travel logistics and sample holding limitations. Therefore, collecting sample replicates and comprehensive datasets suitable for statistical analysis is highly constrained in these regions. As a consequence, there is a lack of understanding of the environmental risks, system performance, and treatment processes associated with polar treatment systems (Chouinard et al., 2014).

Some studies have been performed in Arctic environments for the screening of pharmaceuticals and personal care products in wastewaters. For example, Weigel et al. (2004) characterized selected pharmaceuticals in the sewage of Tromsø, Norway and in the seawater of Tromsø-sound, receiving these wastewaters. These chemicals included ibuprofen and its metabolites, the insect repellent $\mathrm{N}, \mathrm{N}$-diethyl-3-toluamide, as well as caffeine, included as a tracer for domestic sewage. Emnet et al. (2015) studied the occurrence of personal care products in two Antarctic research stations, detecting six analytes in treated wastewaters, including the UV filters 4-methyl-bezylidene camphor, 2-hydroxy-4methoxybenzophenone and 2,4-dihydroxybenzophenone, the plastic monomer 2,2-bis(4-hydroxyphenyl)-propane, the steroid hormone estrone and the antimicrobial triclosan. These compounds were detected at concentrations comparable to those reported for international coastal waters next to significantly greater human populations (Balmer et al., 2005).

In many regions of the Arctic, the release of sewage with minimum or no treatment can have consequences for the receiving environment, given the high vulnerability of the Arctic ecosystem to environmental contaminants (Gunnarsdottir et al., 2013). Kallenborn et al. (2008) reported that pharmaceutical residues are degraded slower in Arctic environments compared to release scenarios in lower latitudes. In their study a set of nine different antidepressants and their transformation products were analyzed in receiving seawater from two locations in Norway, one of them in a northern region. Increased environmental stability of these compounds was detected in the Arctic environment compared to the temperate location. The removal of pharmaceutical residues by photodegradation is limited during the Arctic polar night and the intensity of sunlight (even continuously during periods of midnight sun) at other times of the year is less intense than that of more temperate regions. Both limited photodegradation during the winter and the cold Arctic climate can slow down the degradation rate of pharmaceutical residues in the environment (Schwarzenbach et al., 2003).

Arctic communities frequently experience several challenges in order to perform adequate treatment of their wastewaters. Characteristics such as geographical remoteness, adverse weather and lack of basic services are common in many communities and make wastewater treatment, whenever possible, a difficult task (Yates et al., 2012). The scarcity of accredited laboratories for compliance testing and the necessity for trained personnel to manage wastewater facilities are challenges that need to be overcome by these communities on a daily basis. Also, subsistence fishing is a significant industry in many Arctic coastal regions, for which pollutant contamination of marine species is a major concern. Exposure to micropollutants and their uptake in the food web can have hazardous effects on human health and the environment through bioaccumulation and biomagnification of chemicals
(Gunnarsdottir et al., 2013). With regards to human health, the Canada Health Act mandates that the majority of health services are publicly funded and available for all Canadians, with administration at provincial and territorial levels. However, differences do exist in the health status of aboriginal and non-aboriginal Canadians. For example, First Nations populations experience greater rates of mental illness, suicide, diabetes, asthma, cardiovascular disease, tuberculosis, hepatitis, syphilis and HIV/AIDS than non-aboriginal populations (Romain, 2013). This can influence the amount of pharmaceuticals that are needed to treat these diseases in Northern Canadian communities.

To begin to address the need for knowledge about wastewater contaminants exposure in the Arctic, it is needed to quantify the types and quantities of nutrients and micropollutants in lagoon discharge effluents and receiving waters. Such an effort would allow a partial understanding of the possible hazards associated with wastewater discharges into receiving environments. In this study, we examined the efficacy of wastewater treatment under arctic conditions, by assessing the occurrence of selected wastewater contaminants attenuation and release from a wastewater treatment facility in Cambridge Bay, Nunavut, Canada. Our objectives were: first, to obtain recent exposure data for the wastewater contaminants in Cambridge Bay, regarding to the concentrations of nutrients (total nitrogen and phosphorus), ARGs and pharmaceuticals; and second, to provide a baseline of the current state of wastewater treatment in Cambridge Bay, in anticipation of the eventual instalment, expected by 2017, of the Canadian High Arctic Research Station (CHARS), a scientific facility for Arctic research, as well for expanding populations in the Arctic in general. Of particular interest was the exposure data at the water intake point that CHARS will eventually use for research purposes. We were also interested on assessing the facility for evidence of any leaky sewage infrastructures, specifically at Finger Bay. We hypothesize that the wastewater contaminants in Cambridge Bay do not pose a significant risk at this time to the marine environment, and that the lagoon-wetland system in this community has the ability to perform partial attenuation on nutrients, pharmaceuticals and antibiotic resistance genes.

\section{Materials and methods}

\subsection{Study location}

Cambridge Bay is located in the territory of Nunavut in the Canadian Arctic. It has a population of approximately 1400 . Mean monthly temperatures range from a daily maximum and minimum, respectively, of $-28{ }^{\circ} \mathrm{C}$ and $-35^{\circ} \mathrm{C}$ in January to $13^{\circ} \mathrm{C}$ and $5{ }^{\circ} \mathrm{C}$ in July (Government of Canada, 2014). The opening of CHARS in 2017 will likely have an impact in the community in terms of increases in population and use of water resources, including wastewater disposal and treatment.

The wastewater system monitored at Cambridge Bay is comprised of a wastewater lagoon, formerly a series of natural lakes, that performs primary treatment and is discharged once a year, during the summer, into a small hydrologically-isolated natural tundra wetland. Wastewater then is released through an open channel into the marine environment. Municipal sewage from household sewage tanks is regularly transported to the lagoon by sewage trucks that perform dumping runs year-round.

\subsection{Sample collection}

The selection of sampling sites was done in consultation with local municipal authorities with an overarching aim of characterizing the composition of wastewaters and receiving waters for the 
target analytes. Water was sampled from six selected locations around the study site (Fig. 1). These were: approximately $20 \mathrm{~m}$ away from a new wastewater drop off point (Lagoon Input 1); approximately $20 \mathrm{~m}$ away from an older drop off point (Lagoon Input 2); at the outflow of the natural tundra wetland (Wetland); approximately $100 \mathrm{~m}$ offshore of the primary discharge point (approximately $100 \mathrm{~m}$ from the Wetland site) to the bay (Outfall); at the CHARS' proposed seawater intake point (CHARS); and at a previously used run-off discharge point culvert, currently closed, located around $300 \mathrm{~m}$ west from the main discharge point (Finger Bay). No significant rain events were registered during the sampling. Pharmaceuticals were passively sampled using triplicate POCIS (Environmental Sampling Technologies, St Joseph, MO) in the "pharmaceutical" configuration as described by MacLeod and Wong (2010). Sampling was performed both before and during release of wastewater from the lagoon. Pre-release POCIS sampling was performed from July 25 to August 8, 2014 for inland locations, and from July 26 to August 9 for offshore locations. Wastewater release occurred from August 28 to September 5 with POCIS sampling performed from August 29 to September 8 at all locations. Grab-sampling for nutrients (composite sample) and ARGs (triplicates) was conducted on July 25 in the pre-release stage, and on September 3 during release. Field blanks immersed in nanopure water (18 M $\Omega-\mathrm{cm}$, Millipore, Billerica, MA) in the appropriate containers were opened during sampling to determine the extent of contamination. Samples were kept on ice within $24 \mathrm{~h}$ after the sampling for transport to the local laboratory, and shipped on ice back to Winnipeg for processing. Samples for nutrients were collected in $50 \mathrm{~mL}$ falcon tubes. Personnel wore gloves disinfected with 70\% isopropanol, while handling ARG samples, which were collected in autoclaved $500 \mathrm{~mL}$ polyethylene bottles pre-release (July 25) and during release (September 3) from all sampling locations. Bottles were rinsed three times with sample water before being filled to the top with no headspace. Field blanks filled with nanopure water (18 M $\Omega-\mathrm{cm}$, Millipore, Billerica, MA) in the appropriate containers were opened during sampling to determine the extent of contamination. Samples were kept on ice within $24 \mathrm{~h}$ after the sampling for transport to the laboratory, where ARGs samples were filtered in a sterile environment. These filters were kept at $-20^{\circ} \mathrm{C}$ until shipment to the University of Strathclyde for ARG analysis.

\subsection{Determination of pharmaceuticals and nutrients}

We followed the methods of Carlson et al. (2013), for the analysis of pharmaceuticals. Ultra high-performance liquid chromatography-tandem mass spectrometry (UHPLC/MS/MS) with isotope dilution was used to quantify chemicals of interest in water

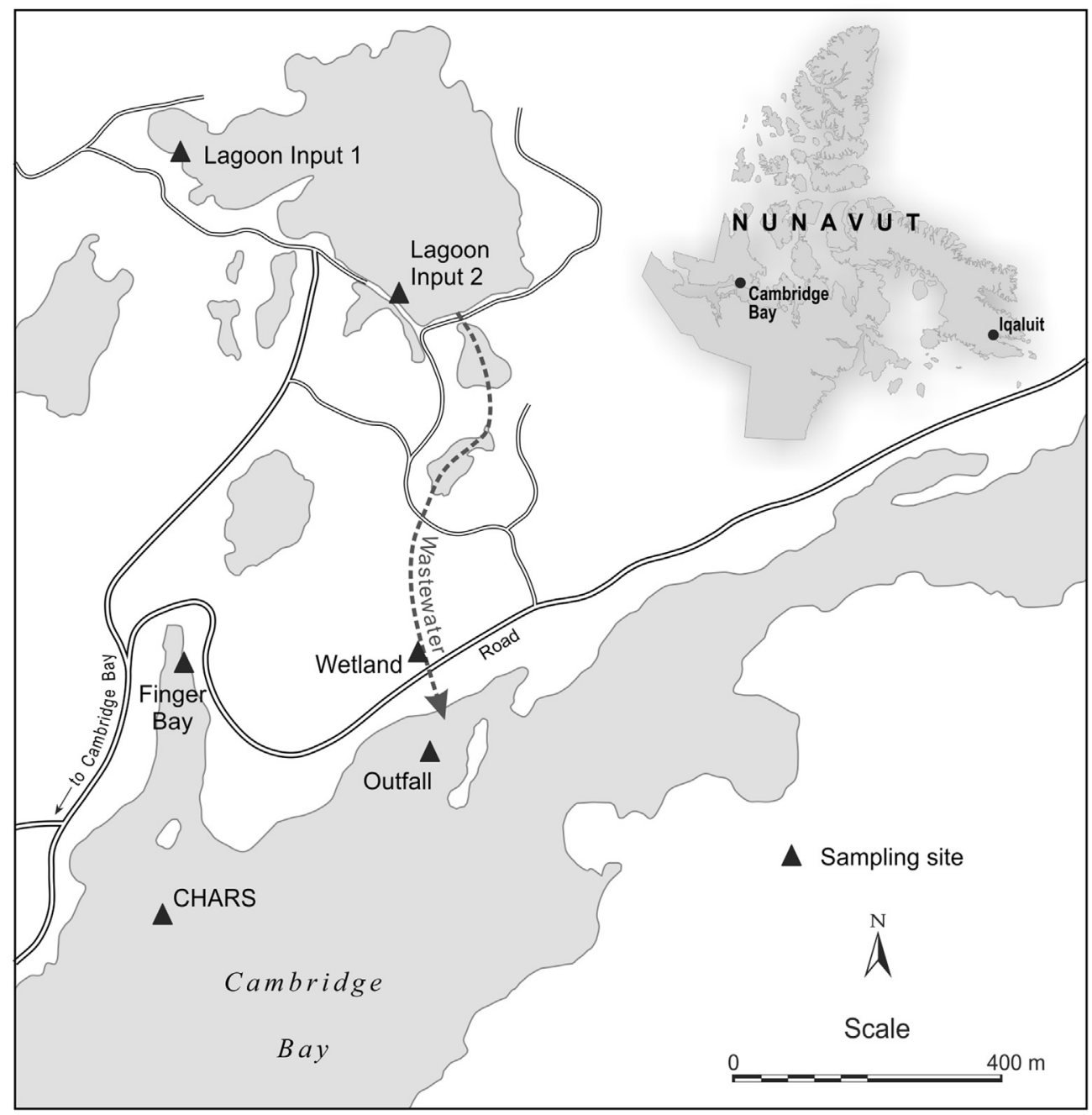

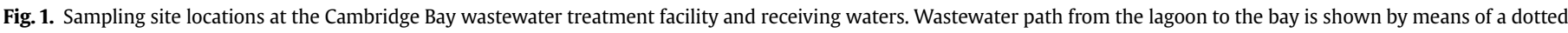
line. 
samples. These compounds included a suite of twenty-eight commonly-used micropollutants frequently found in wastewaters (Fatta-Kassinos et al., 2011), including $\beta$-blockers (e.g. metoprolol); antidepressants (e.g. fluoxetine); anticonvulsant drugs (e.g. carbamazepine) and macrolide (e.g. clarithromycin) and sulfonamide (e.g. sulfamethazine) antibiotics. Limits of quantification (LOQ) are found in Table S1, and other quality assurance/quality control parameters details in Carlson et al. (2013). Time-weighed average (TWA) concentrations were calculated by dividing the determined mass of chemical (ng) in the sampler by the sampling rate $(\mathrm{L} / \mathrm{d})$ times the deployment time (d) for all detected micropollutants, making use of sampling rates (Table S2) found in the literature (MacLeod et al., 2007; Bartelt-Hunt et al., 2011). Concentrations of nutrients (e.g. total nitrogen and total phosphorus) were determined before and during discharge following standard methods (APHA, 2005).

\subsection{Hazard assessment for detected pharmaceuticals}

A hazard assessment was performed for detected compounds by calculating hazard quotients (HQs) using standard tests and endpoints from aquatic toxicological studies, particularly for primary producers, invertebrates and fish. Briefly, estimates for effective concentrations (EC50) or lethal concentrations (LC50) were obtained through a literature search without any assessment of study quality. For added conservatism, we employed an uncertainty factor of 1000 to the lowest EC50 or LC50S as is typically done. The maximum measured environmental concentration was then divided by the lowest reported effect concentration (typically freshwater, as marine organism tests were lacking) to obtain the hazard quotient. Hazard quotients greater than 1 were considered to be of concern while those compounds with HQ values less than 1 were considered less likely to pose a concern.

\subsection{Determination of antibiotic resistance genes}

Antibiotic resistance genes were quantified from cells harvested on filters following cell disruption (FastPrep, MP Biomedicals; 2 cycles at $30 \mathrm{~s}$ each at 6.0 setting) and DNA purification (MoBio PowerClean Soil DNA kit; Cambio, Cambridge, UK), similar to methods previously used (Anderson et al., 2015; Cardinal et al., 2014). A multiplex assay was used to target an array of tetracycline resistant genes (Ng et al., 2001), sulfonamide resistant genes (Pei et al., 2006) and 16S-rRNA was quantified as a measure of 'total bacteria'. Quantitative PCR was conducted using a BioRad iQ cycler (BioRad, Hercules, CA) using ssoFast EvaGreen reagents (BioRad) and $500 \mathrm{nM}$ primer concentrations. All samples were diluted 1:100 with molecular grade water, as reactions were predetermined to be most efficient at those sample concentrations; standards and postanalytical melting curves were generated (Smith et al., 2004) to verify PCR reactions quality and quantify results.

\subsection{Statistical analysis}

Changes in concentrations of pharmaceuticals, as well as abundance of ARGs, from before and during release were assessed using a Student's paired $t$-test. Concentration data are presented as mean \pm standard deviation (St. Dev.) unless otherwise indicated. Differences were considered significant at $\mathrm{p}<0.05$.

\section{Results and discussion}

\subsection{Nutrients}

concentrations at many sites, particularly those offshore given very low levels there (Table 1 ). Thus, only a single measurement was made per site per sampling time, so our discussion of changes in concentrations is qualitative in nature.

Total nitrogen showed values over $10 \mathrm{mg} / \mathrm{L}$ for the lagoon sites both before and during release measurements. Concentrations at Lagoon Input 1 and Lagoon Input 2 showed similar levels at both times, with the Wetland site having an increase in concentration after the wastewater discharge started. There was no apparent reduction in the concentration of nitrogen in the lagoon or the wetland in the two time periods. Locations offshore (e.g. Outfall, CHARS) showed much lower concentrations. Total phosphorus levels were approximately $2 \mathrm{mg} / \mathrm{L}$ for both lagoon sites prior to wastewater discharge. After the discharge commenced, phosphorus levels in the wetland were elevated to approximately $2 \mathrm{mg} /$ $\mathrm{L}$ as well, with no apparent reduction from additional wetland treatment. Phosphorus levels appear to be greater and nitrogen values appear to be lesser than the maximum values recommended for Canadian provinces such as Manitoba, in which limits of $1 \mathrm{mg} / \mathrm{L}$ total phosphorus and $15 \mathrm{mg} / \mathrm{L}$ total nitrogen exist for wastewater effluents discharged to a water body (Manitoba Water Stewardship, 2011). However, policies for communities in the far north have not yet been defined and a joint governmental commission has been assigned to define them by 2019 (CCME, 2014). Considerable dilution was observed for all locations offshore (e.g. Outfall, CHARS), which was consistent with the nitrogen measurements. Finger Bay showed reduced levels for both total nitrogen and phosphorus, which suggests that there is little possibility of runoff from the main lagoon to this location contrary to prior speculations that this was a route of contamination from the lagoon to the bay. The levels of phosphorus we measured pre-release are comparable to that in the water column at the center of Cambridge Bay and at Dease Strait, a waterway immediately west of Cambridge Bay (0.01-0.04 mg/L, C. J. Mundy, unpublished data). Surface concentrations of phosphorus at the Outfall site are roughly twice those levels, suggesting the possibility of localized effects of phosphorus that are not evident at points farther away in the bay (Table 1). While nutrient levels during release are likely locally elevated relative to concentrations in the greater Canadian Arctic (Tremblay et al., 2015), more work is warranted to examine to what extent these added nutrients may influence the local ecosystem of Cambridge Bay and Dease Strait.

No apparent nutrient removal was observed during discharge as a result of lagoon-wetland treatment. As noted, statistical analysis of nutrient concentrations was not possible. Nor can we rule out the possibility that nutrient concentrations may have been affected by heterogeneous distributions within different locations of the lagoon. That having been said, the data obtained in this study differ from the results obtained in a previous work by Yates et al. (2012), in which three larger lagoon-wetland systems in Nunavut (Arviat, Whale Cove and Coral Harbour) were studied, observing reductions up to $84-99 \%$ for $\mathrm{NH}_{3}-\mathrm{N}$ and $80-99 \%$ for total phosphorus. It is known that the community of Arviat makes use of berms and channels to direct wastewater flow away from the ocean and to keep a longer residence time in the wetland (Wootton et al., 2008), whereas in the Cambridge Bay wetland, the residence time of wastewater is limited by the landscape topography and the scarce available vegetation. It is yet unclear which mechanisms play the most important role in wastewater treatment in the Arctic. Wetland size and vegetation coverage, as well as the potential for filtration and sedimentation of suspended solids, and adsorption of nutrients within the soil and water column can play a significant role. 
Table 1

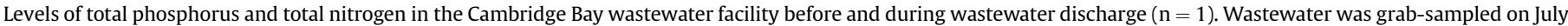

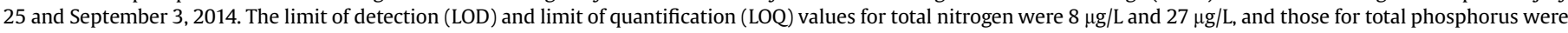
$0.58 \mu \mathrm{g} / \mathrm{L}$ and $1.85 \mu \mathrm{g} / \mathrm{L}$, respectively.

\begin{tabular}{|c|c|c|c|c|}
\hline \multirow[t]{2}{*}{ Sampling site } & \multicolumn{2}{|l|}{ Before discharge } & \multicolumn{2}{|l|}{ During discharge } \\
\hline & Total phosphorus (mg/L) & Total nitrogen $(\mathrm{mg} / \mathrm{L})$ & Total phosphorus (mg/L) & Total nitrogen $(\mathrm{mg} / \mathrm{L})$ \\
\hline Lagoon Input 1 & 2.4 & 12.6 & 2.8 & 12.0 \\
\hline Lagoon Input 2 & 2.4 & 16.6 & 2.8 & 13.5 \\
\hline Wetland & 0.7 & 0.4 & 2.5 & 13.3 \\
\hline Outfall & 0.01 & 0.3 & 0.07 & 0.4 \\
\hline Finger Bay & 0.01 & 0.3 & 0.03 & 0.3 \\
\hline CHARS & 0.02 & 0.4 & 0.03 & 0.3 \\
\hline
\end{tabular}

\subsection{Pharmaceuticals}

Of the screened twenty-eight organic micropollutants, only six pharmaceuticals were detected above their LOQ at any of the locations. These were atenolol, clarithromycin, metoprolol, sulfamethoxazole, trimethoprim and carbamazepine, detected at least once at ng/L levels (Fig. 2). For the detected pharmaceuticals, the greatest concentrations were measured at the Lagoon Input 1 and 2 sites, although some differences in concentration could be seen between both of the dumping sites. Most locations offshore experienced considerable dilution with seawater, which was reflected in significantly lower concentrations for all of the passively sampled contaminants at Outfall, CHARS and Finger Bay. Although POCIS deployment times were different before and during discharge (14

\section{Atenolol}

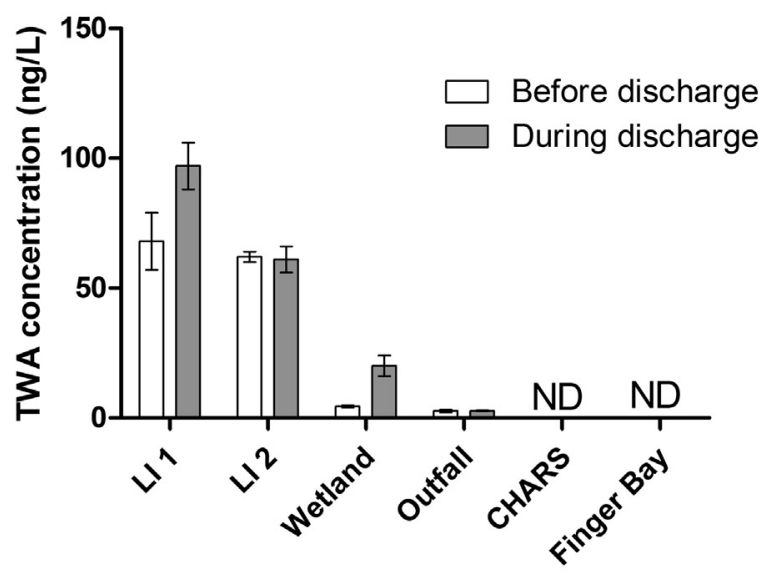

Sampling sites

\section{Sulfamethoxazole}

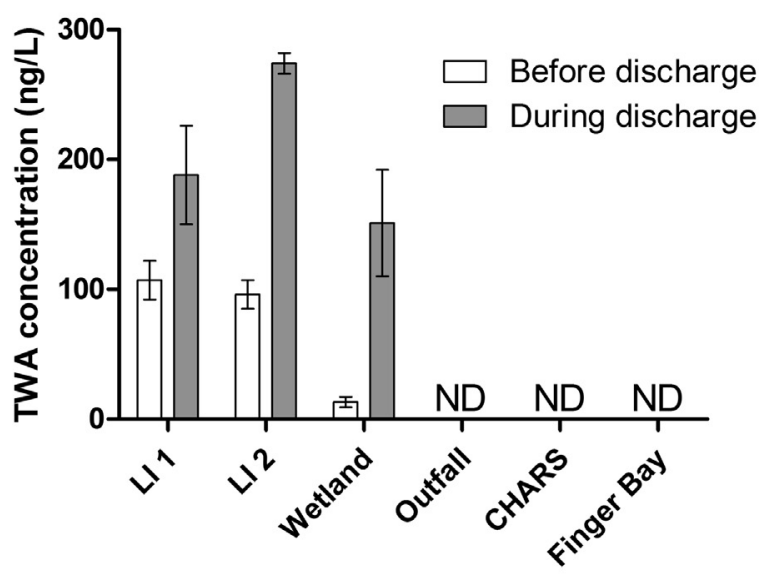

Sampling sites

\section{Carbamazepine}

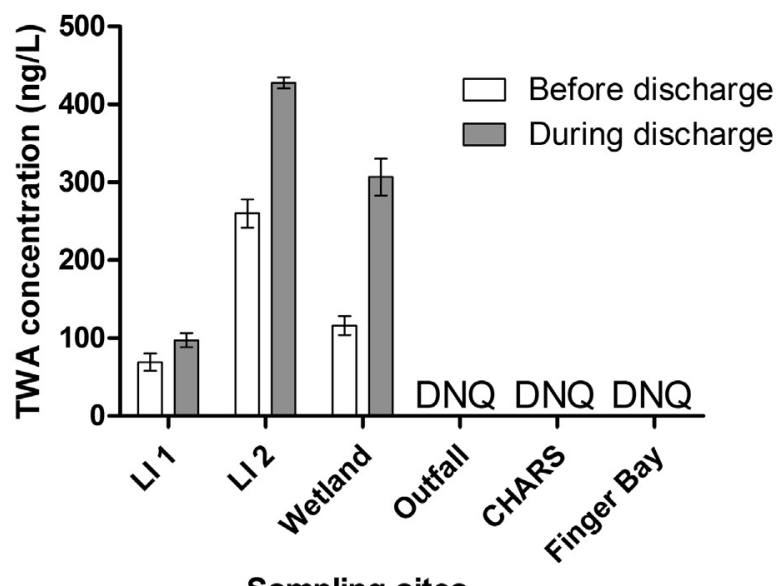

Sampling sites

\section{Trimethoprim}

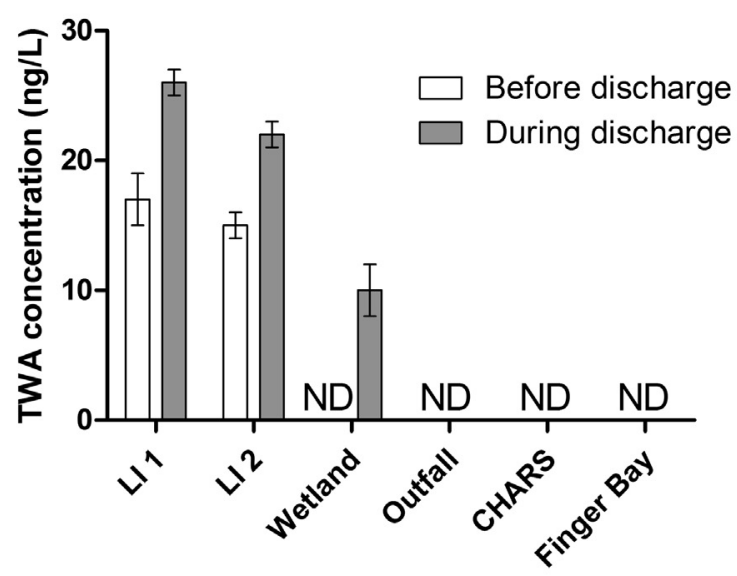

Sampling sites

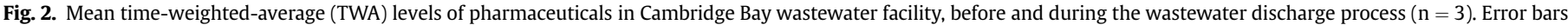

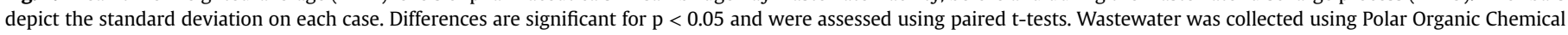
Integrative Samplers from July 25 to August 8, from July 26 to August 9 and from August 29 to September 8, 2014. ND: below limit of detection (LOD). DNQ: did not quantify. 
days versus 9 days), steady state conditions for POCIS are typically reached within six days (Vermeirssen et al., 2012).

The greatest concentration of atenolol was $97 \mathrm{ng} / \mathrm{L}$ (Lagoon Input 1$)$. Detected levels were significantly different $(\mathrm{p}<0.05)$ between Lagoon Input 1 and Lagoon Input 2 sites both before and during the discharge. There was a significant reduction of $45 \%$ observed between Lagoon Input 2 and Wetland $(p<0.05)$ during the wastewater release, and heavy dilution at locations offshore, with most sites observed to be at non-detectable levels. These results suggest processes within the wetland (e.g. sorption to plants, microbial degradation) may reduce concentrations of atenolol under Arctic conditions. A more efficient removal of atenolol has been observed in more southern locations in Canada, with removal rates up to $98 \%$ for example within a sewage lagoon in Dunnottar, Manitoba under temperate conditions (Anderson et al., 2015).

Concentrations of carbamazepine were generally below $100 \mathrm{ng} /$ $\mathrm{L}$ in both lagoon sites, with greater concentrations reported in the Wetland site both before and during discharge. No apparent removal was observed as a result of wastewater passage through the treatment wetland ( $\mathrm{p}<0.05$ ). Offshore locations showed levels below LOQ. Persistence of carbamazepine during the Arctic winter was observed, with a concentration of $116 \mathrm{ng} / \mathrm{L}$ in the hydrologically isolated wetland prior to discharge. While no measurements of pharmaceuticals occurred during the winter, we note that this shallow wetland system and the offshore locations are essentially frozen over completely during the winter. This would presumably result in no chemical removal, either by microbial activity or photodegradation (i.e., ice cover would block light penetration) until summer melt.

The greatest concentration of sulfamethoxazole was $274 \mathrm{ng} / \mathrm{L}$; this was detected at the Lagoon Input 2 site during wastewater discharge. Concentrations between lagoon sites were significantly different both before and during discharge $(\mathrm{p}<0.05)$, with some attenuation observed after wetland treatment, reaching $151 \mathrm{ng} / \mathrm{L}$ ( $45 \%$ removal, $\mathrm{p}<0.05$ ). Levels offshore were non-detectable both before and during discharge. Unlike this study, Conkle et al. (2008) noted over $90 \%$ removal of sulfonamides on a temperate wastewater facility, however, the differences may have been as a result of significantly greater temperatures and a 27-day retention period compared to a drastically colder weather and shorter retention time at Cambridge Bay facility of 1-2 days.

Trimethoprim was detected in concentrations under $30 \mathrm{ng} / \mathrm{L}$ at the lagoon and wetland sites. During wastewater release, the wetland concentration was $9.8 \mathrm{ng} / \mathrm{L}$ after significant attenuation ( $p<0.05$ ) occurred between the lagoon and the wetland. Finally, clarithromycin and metoprolol were detected at both of the lagoon sites and also in the wetland at levels below LOQ. At the offshore sites, both compounds were non-detectable, which is consistent with what was observed for all contaminants studied.

The presence or absence of specific pharmaceuticals depends partially on the residence time within sewage holding tanks, prior to entry into sewage lagoons. While photodegradation is unable to occur in septic tanks, other degradative processes like anaerobic microbial-mediated biotransformation could occur. Consequently, the most labile compounds were likely partially degraded to an unknown extent. Sorption of pharmaceuticals to septic tank particulates may also occur. Phototransformation and biotransformation are typically the most important processes for degrading organic micropollutants in effluent-receiving waters. Consequently, optimizing conditions for these processes (e.g. by using extended periods of treatment in sewage lagoons) can mitigate environmental exposure to biologically active levels of these contaminants (Ying et al., 2009).

To our knowledge, there are no reported data for pharmaceuticals from wastewater systems from Northern Canada. Nevertheless, a larger amount of information (Table 2) is available for treated lagoon wastewaters using passive sampling of more southern regions in Canada, including various works done in the province of Manitoba (Anderson et al., 2013, 2015; Carlson et al., 2013) and Alberta (MacLeod and Wong, 2010). At Cambridge Bay, all detectable compounds had greatest concentrations at either the lagoon or the wetland sites and were mostly non-detectable at locations offshore. Atenolol, carbamazepine, sulfamethoxazole and trimethoprim were detected in the Cambridge Bay facility at lower levels compared to the data obtained at Dunnottar, Manitoba (Anderson et al., 2015). On the other hand, atenolol, sulfamethoxazole and trimethoprim were detected in greater levels than in the Grand Marais wastewater treatment facility. Levels of drugs were similar in wastewaters of Cambridge Bay and Lac la Biche, Alberta (MacLeod and Wong, 2010).

There are several factors that likely account for the differences in pharmaceutical levels among these locations. One factor is population, with greater populations implying greater loadings and impact on wastewater release. The populations served by the treatment facilities of the southern Canadian sites (Table 2) are all on the order of several thousand, with some seasonal variability. For example, the Dunnottar population, a popular regional summer resort (Anderson et al., 2015) is several times greater than that of Cambridge Bay during the summer. However, similar per capita use of drugs may result in similar concentrations in wastewaters (MacLeod and Wong, 2010), which appears to be the case based on our comparisons (Table 2). Another factor is temperature, given the fact that colder temperatures in Nunavut can cause treatment mechanisms such as sorption to be slower and less efficient when compared to temperate locations, as it has been previously observed in Norway (Kallenborn et al., 2008). Both factors are likely in play, confounding prediction of pharmaceutical levels in wastewaters.

\subsection{Risk assessment for detected pharmaceuticals}

Hazard quotients (HQs) were calculated for each organic contaminant based upon toxicity data reported in the literature for primary producers, invertebrates and fish (Table S3). Most compounds had an HQ less than 1, ranging from values between $10^{-6}$ and $10^{-1}$. Only clarithromycin presented an HQ greater than 1 for the alga Pseudokirchneriella subcapita, which indicates that there is a potential for growth inhibition of algal species at concentrations

Table 2

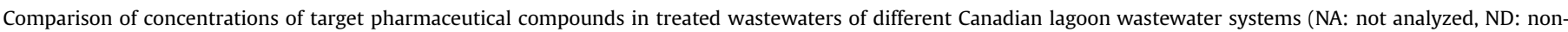

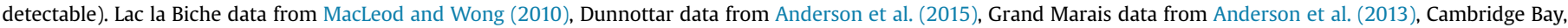
this study. Populations are shown underneath the name of each location for comparison.

\begin{tabular}{|c|c|c|c|c|}
\hline Location & Atenolol (ng/L) & Carbamazepine (ng/L) & Sulfamethoxazole (ng/L) & Trimethoprim (ng/L) \\
\hline Lac la Biche, $\mathrm{AB}(8,402)$ & ND - 100 & $50-300$ & NA & $10-15$ \\
\hline Dunnottar, MB (692) & ND - 856.5 & $20.1-426.1$ & ND - 1252.5 & ND - 318.5 \\
\hline Grand Marais, MB (252) & ND & $85-500$ & ND-21 & ND \\
\hline Cambridge Bay, NU $(1,400)$ & ND - 97.4 & $1.2-428$ & ND - 274 & ND - 25.7 \\
\hline
\end{tabular}


such as those detected in lagoon and in the wetland. While the HQ for clarithromycin was greater than 1 , the concentration level used for calculation may not be necessarily representative of what could be found in the entire lagoon. As well, the use of a 1000-fold uncertainty factor adds a high degree of conservatism, and there was no apparent risk posed to receiving waters. As well, in eutrophic environments, such as these lagoons, excess nutrients can mitigate the effects of compounds that exhibit herbicidal activity (Baxter et al., 2013). For the rest of the detected pharmaceuticals, we can conclude that there is likely no significant hazard to aquatic life due to the low concentrations at which they were detected. We did lack Arctic and marine-specific tests that would reduce the uncertainty and did not assess for the effect of mixtures of chemical stressors. We do recommend the development of standard toxicity tests with Arctic marine organisms to help address this uncertainty.

\subsection{Abundances and removal of ARGs}

Total bacterial populations were determined by means of the abundances of 16S rRNA genes. Their presence was greatest in the lagoon sites in both sampling periods: before the wastewater discharge started $\left(10^{8.0}\right.$ genes/mL in Lagoon Input 1 and $10^{7.8}$ copies/mL in Lagoon Input 2), and during wastewater discharge $\left(10^{7.4}\right.$ genes $/ \mathrm{mL}$ in Lagoon Input 1 and $10^{7.5}$ copies $/ \mathrm{mL}$ in Lagoon Input 2) (Table 3). Overall, the abundances of 16S rRNA genes were similar (i.e., differences found were not greater than one order of magnitude) to levels reported at more southern locations in Canada (Anderson et al., 2015). Comparing concentrations before and during wastewater discharge, gene abundances did not change significantly (paired $t$-test, $\mathrm{t}_{5}=-1.46, p=0.203$ ) and their distribution pattern remained similar $(r=0.965, p=0.002)$ along the waste stream.

Clusters of tetracycline resistance and sulfonamide-resistance genes were analyzed and the results were summed to facilitate assessment of resistance patterns. The greatest abundances of tet ${ }^{R}$ (sum of tetracycline resistance genes) and sul ${ }^{\mathrm{R}}$ (sum of sulfonamide resistance genes) were found in the primary lagoon, at the two wastewater drop-off locations, being Lagoon Input 2 the one with the greatest response, with some attenuation through the wetland (Table 3).

Specifically in terms of the tetracycline resistance genes, differences from lagoon levels to offshore levels were around one order of magnitude during discharge, with locations after the wetland having reductions most likely due to dilution. Outfall was the sampling spot with the lower amount of tet ${ }^{\mathrm{R}}$ genes before and after discharge. Distribution of concentrations before and during discharge was similar $(r=0.941, p=0.005)$, but became lower after discharge (paired $t$-test, $t_{5}=3.66, p=0.015$ ) quite possibly due to dilution with water from the environment (e.g. existing surface water).
Sulfonamide resistance genes were more highly concentrated in the lagoon and wetland, and before discharge declined rapidly (2-3 orders of magnitude) following the wetland. During discharge, gene concentrations were variable at the two drop-off points in the lagoon, with minimum to no attenuation from the wetland. Gene distribution patterns along the waste stream were comparable (before-during discharge; $r=0.887, p=0.019$ ), but unlike 'total tet' there were significant pairwise changes (paired $t$ test, $t=0.506, p=0.634$ ) as most concentrations declined, except at the wetland and slightly in CHARS site.

To facilitate further analysis in prevalence of bacteria throughout the treatment process, abundances of resistance genes were divided by the abundance of $16 \mathrm{~S}$ rRNA genes to represent relative gene abundances. Relative abundances of ARGs were low (e.g. less than $2 \%$ of the total as observed in the wetland) at all locations during discharge (see Table 3 ), which suggests a low potential for ARG-bearing bacteria to exist throughout the treatment system. Tetracycline resistance genes remain elevated in wastewater systems if there is a source of resistance microorganism and tetracycline usage (Peak et al., 2007), but can decline in sunlightexposed systems over a relatively short period of time (Engemann et al., 2008; Zhang et al., 2009). This suggests that tetracycline may not have been extensively used in the Cambridge Bay population around the times of sampling. Gene concentrations were equivalent to wastewater lagoons with minimal tetracycline usage by source population e.g., (Peak et al., 2007), and could already represent near-background levels (Engemann et al., 2006; Zhang et al., 2009), which are around $10^{2}$ genes/mL (Graham et al., 2011). Detectable sulfonamide concentrations in this study may have been sufficient to maintain selective pressure for antibiotic-resistant bacteria; alternatively, the presence of elevated levels may represent residual evidence of previously higher levels of sulfonamide usage, as gene fate tends to differ from chemical fate (e.g. Engemann et al., 2006; Peak et al., 2007).

Wastewater systems have a variable ability to reduce antimicrobial resistance, given the fact that generally resistant bacteria numbers decline in wastewater treatment as bacteria are removed. But these patterns require further investigation, as they remain a function of bacterial community and operating conditions (Christgen et al., 2015). Further, no studies to date have examined the fate of antibiotic resistant bacteria in the wastewater stream at lower temperatures, such as in the Arctic. Well-studied coliform bacteria, which tend to carry ARGs, persist longer in colder temperatures (Ŝlić and Krstulović, 1992); however, gene persistence at lower temperatures could be exacerbated by slowed transformation rates of pharmaceutical compounds and prolonged selective pressures, reduced endonuclease activity, and lowered predation. Further investigations are required to fully elucidate gene fate under psychrophilic conditions.

Table 3

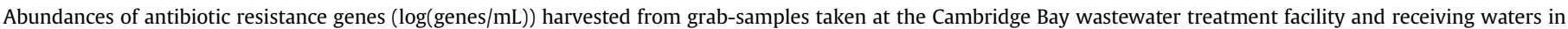

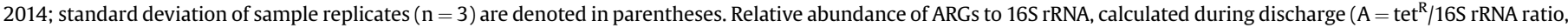
$\mathrm{B}=\mathrm{sul}^{\mathrm{R}} / 16 \mathrm{~S}$ rRNA ratio) is also shown.

\begin{tabular}{|c|c|c|c|c|c|c|c|c|}
\hline \multirow[t]{2}{*}{ Sampling site } & \multicolumn{3}{|c|}{ Before discharge } & \multicolumn{5}{|c|}{ During discharge } \\
\hline & $\log$ total tet ${ }^{R}$ & $\log$ total sul ${ }^{\mathrm{R}}$ & $\log 16 \mathrm{~S}$ rRNA & $\log$ total tet ${ }^{\mathrm{R}}$ & $\log$ total sul $^{\mathrm{R}}$ & $\log 16 S$ rRNA & $A(\%)$ & $\overline{B(\%)}$ \\
\hline Lagoon Input 1 & $4.2(0.3)$ & $4.7(0.5)$ & $8.0(0.5)$ & $3.8(0.2)$ & $4.4(0.3)$ & $7.4(0.4)$ & 0.02 & 0.1 \\
\hline Lagoon Input 2 & $4.3(0.3)$ & $6.0(0.7)$ & $7.8(0.9)$ & $4.1(0.3)$ & $5.6(0.3)$ & $7.5(0.8)$ & 0.03 & 1.3 \\
\hline Wetland & $3.9(0.2)$ & $4.4(0.3)$ & $6.8(0.4)$ & $3.8(0.2)$ & $5.6(0.3)$ & $7.3(0.6)$ & 0.03 & 2.0 \\
\hline Outfall & $2.9(0.2)$ & $2.8(0.2)$ & $5.4(0.4)$ & $2.7(0.2)$ & $1.8(0.1)$ & $6.1(0.4)$ & 0.04 & 0.01 \\
\hline Finger Bay & $3.0(0.1)$ & $2.8(0.2)$ & $5.3(0.2)$ & $2.7(0.2)$ & $2.0(0.2)$ & $6.3(0.4)$ & 0.02 & 0.01 \\
\hline CHARS & $3.7(0.2)$ & $3.0(0.2)$ & $5.2(0.4)$ & $3.0(0.3)$ & $3.3(0.3)$ & $6.3(0.4)$ & 0.05 & 0.1 \\
\hline
\end{tabular}




\section{Conclusions}

Our assessment of the Cambridge Bay wastewater treatment facility allowed us to detect no apparent removal of nutrients as a result of lagoon-wetland treatment. Reduced nutrients concentrations at locations offshore occurred as a result of receiving environment dilution. Our data suggests that some attenuation mechanisms for pharmaceuticals exist in the treatment system, especially in the sewage lagoon and to some extent in the natural wetland. Distribution of the wastewater contaminants within the lagoon sites was not homogeneous, due to the presence of two different drop off points for sewage dumping and the topography of the lagoon. From all of the studied pharmaceuticals, only carbamazepine showed some persistence during the Arctic winter. Atenolol, sulfamethoxazole and trimethoprim had dissipated prior to the first sampling campaign. Concentrations of detected pharmaceuticals and nutrients were minimal in the Finger Bay location, which suggests that there was minimal runoff of wastewater to this point. Hazard assessment for detected pharmaceuticals shows that current concentrations of monitored pharmaceuticals do not pose a significant hazard at this time to aquatic organisms in Cambridge Bay. Bacterial populations were detected in similar levels to more southern Canadian locations, with some ARGs attenuation observed in the lagoon-wetland system and considerable dilution at locations offshore. Finger Bay experienced non-detectable levels for all pharmaceuticals and very low levels of ARGs, which suggests that this location was not likely experiencing any sewage leaking at the time of this study. Overall, the CHARS scientific water supply location showed non-detectable levels for all pharmaceuticals and very low levels of ARGs, prior to the instalment of the facility at Cambridge Bay. This study constitutes one of first attempts ever made to understand the occurrence of pharmaceuticals, ARGs and nutrients on wastewater treatment facilities in the Canadian Arctic, as well as the removal performance of these systems under polar conditions.

\section{Acknowledgments}

We thank Shah Alam, Municipal Planning Engineer in Cambridge Bay, for his help with administrative tasks associated to the execution of this project. Also, we thank Angualik Pedersen and Johann Wagner of CHARS for their valuable help during the sampling period, Weldon Hiebert for his mapping assistance and CHARS and the Arctic Research Foundation for providing logistical support. Our utmost appreciation to the funding sources for this project: The Natural Sciences and Engineering Research Council of Canada (NSERC) through the Northern Research Supplement, CMAR group, Canada Research Chairs Program and Vicerrectoría de Investigación y Extensión del Instituto Tecnológico de Costa Rica. We also wish to thank three anonymous reviewers for helpful comments that contributed to the improvement of this manuscript.

\section{Appendix A. Supplementary data}

Supplementary data related to this article can be found at http:/ dx.doi.org/10.1016/j.envpol.2016.07.036.

\section{References}

Anderson, J.C., Carlson, J.C., Low, J.E., Challis, J.K., Wong, C.S., Knapp, C.W. Hanson, M.L., 2013. Performance of a constructed wetland in Grand Marais, Manitoba, Canada: removal of nutrients, pharmaceuticals, and antibiotic resistance genes from municipal wastewater. Chem. Central J. 7, 54.

Anderson, J.C., Joudan, S., Shoichet, E., Cuscito, L.D., Alipio, A.E.C., Donaldson, C.S., Khan, S., Goltz, D.M., Rudy, M.D., Frank, R.A., Knapp, C.W., Hanson, M.L. Wong, C.S., 2015. Reducing nutrients, organic micropollutants, antibiotic resistance, and toxicity in rural wastewater effluent with subsurface filtration treatment technology. Ecol. Eng. 84, 375-385.

APHA, 2005. Standard Methods for the Examination of Water and Wastewater twenty-first ed. American Public Health Association.

Balmer, M.E., Buser, H.-R., Mller, M.D., Poiger, T., 2005. Occurrence of some organic UV filters in wastewater, in surface waters, and in fish from Swiss lakes. Environ. Sci. Technol. 39, 953-962.

Bartelt-Hunt, S.L., Snow, D.D., Damon-Powell, T., Brown, D.L., Prasai, G., Schwarz, M., Kolok, A.S., 2011. Quantitative evaluation of laboratory uptake rates for pesticides, pharmaceuticals, and steroid hormones using POCIS. Environ. Toxicol. Chem. 30, 1412-1420.

Baxter, L.R., Sibley, P.K., Solomon, K.R., Hanson, M.L., 2013. Interactions between atrazine and phosphorus in aquatic systems: effects on phytoplankton and periphyton. Chemosphere 90, 1069-1076.

Bolong, N., Ismail, A.F., Salim, M.R., Matsuura, T., 2009. A review of the effects of emerging contaminants in wastewater and options for their removal. Desalination 239, 229-246.

Cardinal, P., Anderson, J.C., Carlson, J.C., Low, J.E., Challis, J.K., Beattie, S.A., Bartel, C.N., Elliott, A.D., Montero, O.F., Lokesh, S., Favreau, A., Kozlova, T.A., Knapp, C.W., Hanson, M.L., Wong, C.S., 2014. Macrophytes may not contribute significantly to removal of nutrients, pharmaceuticals, and antibiotic resistance in model surface constructed wetlands. Sci. Total Environ. 482-483, 294-304.

Carlson, J.C., Anderson, J.C., Low, J.E., Cardinal, P., MacKenzie, S.D., Beattie, S.A., Challis, J.K., Bennett, R.J., Meronek, S.S., Wilks, R.P.A., Buhay, W.M., Wong, C.S., Hanson, M.L., 2013. Presence and hazards of nutrients and emerging organic micropollutants from sewage lagoon discharges into Dead Horse Creek, Manitoba, Canada. Sci. Total Environ. 445-446, 64-78.

CCME, 2014. Canada-wide Strategy for the Management of Municipal Wastewater Effluent. 2014 Progress Report. Available online: http://www.ccme.ca/files/ Resources/municipal_wastewater_efflent/PN_1522_MWWE_Five_Year_Rvw 2014.pdf (accesed 15.02.16).

Chouinard, A., Yates, C.N., Balch, G.C., Jørgensen, S.E., Wootton, B.C., Anderson, B.C., 2014. Management of tundra wastewater treatment wetlands within a lagoon/ wetland hybridized treatment system using the SubWet 2.0 wetland model. Water 6, 439-454.

Christgen, B., Yang, Y., Ahammad, S.Z., Li, B., Rodriquez, D.C., Zhang, T., Graham, D.W., 2015. Metagenomics shows that low-energy anaerobic-aerobic treatment reactors reduce antibiotic resistance gene levels from domestic wastewater. Environ. Sci. Technol. 49, 2577-2584.

Conkle, J.L., White, J.R., Metcalfe, C.D., 2008. Reduction of pharmaceutically active compounds by a lagoon wetland wastewater treatment system in Southeast Louisiana. Chemosphere 73, 1741-1748.

Emnet, P., Gaw, S., Northcott, G., Storey, B., Graham, L., 2015. Personal care products and steroid hormones in the Antarctic coastal environment associated with two Antarctic research stations, McMurdo Station and Scott Base. Environ. Res. 136, $331-342$.

Engemann, C.A., Adams, L., Knapp, C.W., Graham, D.W., 2006. Disappearance of oxytetracycline resistance genes in aquatic systems. Fems Microbiol. Lett. 263 $176-182$.

Engemann, C.A., Keen, P.L., Knapp, C.W., Hall, K.J., Graham, D.W., 2008. Fate of tetracycline resistance genes in aquatic systems: migration from the water column to peripheral biofilms. Environ. Sci. Technol. 42, 5131-5136.

Fatta-Kassinos, D., Meric, S., Nikolau, A., 2011. Pharmaceutical residues in environmental waters and wastewater: current state of knowledge and future research. Anal. Bioanal. Chem. 399, 251-275.

Fent, K., Weston, A.A., Caminada, D., 2006. Ecotoxicology of human pharmaceuticals. Aquat. Toxicol. 76, 122-159.

Government of Canada, 2014. Monthly Climate Report for Cambridge Bay. Available online: http://climate.weather.gc.ca/climateData/monthlydata_e.html?timeframe $=3 \& \operatorname{Prov}=\mathrm{NU} \% 20 \% 20 \&$ StationID $=1786 \&$ mlyRange $=1929-01-01 \mid 2014$ $12-01 \&$ Year $=2014 \&$ Month $=5 \& D a y=4$, (accessed 24.01.16.).

Graham, D.W. Olivares-Rieumont, S., Knapp, C.W.. Lima, L., Werner, D., Bowen, E., 2011. Antibiotic resistance gene abundances associated with waste discharges to the Almendares River near Havana, Cuba. Environ. Sci. Technol. 45, 418-424.

Gunnarsdottir, R., Jenssen, P.D., Jensen, P.E., Villumsen, A., Kallenborn, R., 2013. A review of wastewater handling in the Arctic with special reference to pharmaceuticals and personal care products (PPCPs) and microbial pollution. Ecol. Eng. 50, 76-85.

Kallenborn, R.,Fick, J., Lindberg, R., Moe, M., Nielsen, K.M., Tysklind, M., Vasskog, T., 2008. Pharmaceutical residues in Northern European environments: consequences and perspectives. In: Kummerer, K. (Ed.), Pharmaceuticals in the Environment: Sources, Fate, Effects and Risks, third ed. Springer-Verlag Berlin, Heidelberger Platz 3, D-14197 Berlin, Germany, pp. 61-74.

Luo, Y.L., Guo, W.S., Ngo, H.H., Nghiem, L.D., Hai, F.I., Zhang, J., Liang, S., Wang, X.C.C., 2014. A review on the occurrence of micropollutants in the aquatic environment and their fate and removal during wastewater treatment. Sci. Total Environ. 473, 619-641.

MacLeod, S.L., McClure, E.L., Wong, C.S., 2007. Laboratory calibration and field deployment of the polar organic chemical integrative sampler for pharmaceuticals and personal care products in wastewater and surface water. Environ. Toxicol. Chem. 26, 2517-2529.

MacLeod, S.L., Wong, C.S., 2010. Loadings, trends, comparisons, and fate of achiral and chiral pharmaceuticals in wastewaters from urban tertiary and rural aerated lagoon treatments. Water Res. 44, 533-544.

Manitoba Water Stewardship, 2011. Manitoba Water Quality Standards, Objectives 
and Guidelines. Available online: https://www.gov.mb.ca/waterstewardship/ water_quality/quality/pdf/mb_water_quality_standard_final.pdfAccesed. January 23, 2016.

Ng, L.-K., Martin, I., Alfa, M., Mulvey, M., 2001. Multiplex PCR for the detection of tetracycline resistant genes. Mol. Cell. Probes 15, 209-215.

Peak, N., Knapp, C.W., Yang, R.K., Hanfelt, M.M., Smith, M.S., Aga, D.S., Graham, D.W. 2007. Abundance of six tetracycline resistance genes in wastewater lagoons at cattle feedlots with different antibiotic use strategies. Environ. Microbiol. 9, 143-151.

Pei, R., Kim, S.-C., Carlson, K.H., Pruden, A., 2006. Effect of River Landscape on the sediment concentrations of antibiotics and corresponding antibiotic resistance genes (ARG). Water Res. 40, 2427-2435.

Romain, S.J., 2013. Pharmaceutical health care and Inuit language communications in Nunavut, Canada. Int. J. Circumpolar Health 72, 21409.

Rowan, N.J., 2011. Defining established and emerging microbial risks in the aquatic environment: current knowledge, implications, and outlooks. Int. J. Microbiol. 2011, 462832.

Schwarzenbach, R., Gschwend, P., Imboden, D., 2003. Environmental Organic Chemistry, second ed. John Wiley \& Sons, Inc., New Jersey, USA.

Smith, M.S., Yang, R.K., Knapp, C.W., Niu, Y.F., Peak, N., Hanfelt, M.M., Galland, J.C., Graham, D.W., 2004. Quantification of tetracycline resistance genes in feedlot lagoons by real-time PCR. Appl. Environ. Microbiol. 70, 7372-7377.

Smith, V.H., 2003. Eutrophication of freshwater and coastal marine ecosystems - a global problem. Environ. Sci. Pollut. Res. 10, 126-139.

Solić, M., Krstulović, N., 1992. Separate and combined effects of solar-radiation, temperature, salinity, and $\mathrm{pH}$ on the survival of fecal-coliforms in seawater Mar. Pollut. Bull. 24, 411-416.

Tremblay, J.-É., Anderson, L.G., Matrai, P., Coupel, P., Belanger, S., Michel, C.,
Reigstad, M., 2015. Global and regional drivers of nutrient supply, primary production and $\mathrm{CO} 2$ drawdown in the changing Arctic Ocean. Prog. Oceanogr. 139, 171-196.

Vasskog, T., Bergersen, O., Anderssen, T., Jensen, E., Eggen, T., 2009. Depletion of selective serotonin reuptake inhibitors during sewage sludge composting Waste Manag. 29, 2808-2815.

Vermeirssen, E.L.M., Dietschweiler, C., Escher, B.I., van der Voet, J., Hollender, J. 2012. Transfer kinetics of polar organic compounds over polyethersulfone membranes in the passive samplers POCIS and Chemcatcher. Environ. Sci. Technol. 46, 6759-6766.

Weigel, S., Berger, U., Jensen, E., Kallenborn, R., Thoresen, H., Hühnerfuss, H., 2004 Determination of selected pharmaceuticals and caffeine in sewage and seawater from Tromsø/Norway with emphasis on ibuprofen and its metabolites. Chemosphere 56, 583-592.

Wootton, B., Durkalec, A., Ashley, S., 2008. Canadian Council of Ministers of the Environment Canada-wide Strategy for the Management of Municipal Wastewater Effluent: Nunavut Regional Impact Analysis. Inuit Tapiriit, Katanami, Ottawa, ON.

Yates, C.N., Wootton, B.C., Murphy, S.D., 2012. Performance assessment of arctic tundra municipal wastewater treatment wetlands through an arctic summer. Ecol. Eng. 44, 160-173.

Ying, G.G., Kookana, R.S., Kolpin, D.W., 2009. Occurrence and removal of pharmaceutically active compounds in sewage treatment plants with different technologies. J. Environ. Monit. 11, 1498-1505.

Zhang, W., Sturm, B.S.M., Knapp, C.W., Graham, D.W., 2009. Accumulation of tetracycline resistance genes in aquatic biofilms due to periodic waste loadings from swine lagoons. Environ. Sci. Technol. 43, 7643-7650. 